Review article

\title{
The impact of family intervention programs on the caregiver burden of hemodialysis patients
}

\author{
Vincencius Surani ${ }^{1 *}$, Dewi Elizadiani Suza ${ }^{2}$, Mula Tarigan ${ }^{3}$ \\ ${ }^{1}$ Universitas Sumatera Utara, Faculty of Nursing, Medan, Indonesia \\ 2 Universitas Sumatera Utara, Faculty of Nursing, Department of Pediatric Nursing, Medan, Indonesia \\ ${ }^{3}$ Universitas Sumatera Utara, Faculty of Nursing, Department of Medical Surgical Nursing, Medan, Indonesia
}

\begin{abstract}
Aim: Family caregivers of hemodialysis patients play a vital role in the health sector. However, the care they provide (especially over a long period of time) can cause fatigue, stress, and create a burden for them. Therefore, the aim of this review is to evaluate the effect of family intervention programs in reducing the burdens of family caregivers.

Methods: This is a systematic review, and the database used in the article search included EBSCO, ProQuest, and PubMed (using relevant keywords based on the topic and research title). The Preferred Reporting Items for Systematic Reviews and Meta-Analysis (PRISMA) flow diagram was used in selecting a total of 2,052 articles. 8 were obtained according to the inclusion criteria and were analyzed in a descriptive narrative approach.

Results: The 8 articles with family-based intervention programs consisting of family-centered interventions, educational interventions, and psychological interventions showed significant results in reducing the burdens of caregivers who take care of hemodialysis patients. Conclusions: The results of this systematic review show that intervention programs could help reduce the burdens of family caregivers when caring for hemodialysis patients.
\end{abstract}

Keywords: Burden; Caregiver; Family; Hemodialysis

\section{Introduction}

Chronic kidney disease (CKD) is a condition characterized by abnormalities in the structure and function of the kidneys which lasts for more than 3 months, along with a decrease in glomerular filtration rate (GFR) to less than $60 \mathrm{ml} / \mathrm{min} /$ $1.73 \mathrm{~m}^{2}$ (KDIGO, 2017). Currently, this is considered a challenge to public health (Sanyaolu et al., 2018), and the prevalence rate of this disease has always increased annually. For example, in 2013 there were about 843.6 million cases of this disease, and this increased to 860.8 million in 2017 (Jager et al., 2019). CKD is closely related to hemodialysis because it is a therapy for people suffering from lack of kidney function (Smeltzer et al., 2010). Furthermore, the number of patients undergoing hemodialysis every year keeps increasing worldwide (USRDS, 2019).

The largest problem that can occur in CKD patients is death. According to Jager et al. (2019), in 2016 the disease ranked in 13 th position in the list of the leading causes of death. In 2040 the disease is predicted to reach 5 th place. Moreover, this disease can also affect the patient's lifestyle, health status, and social role. In the long term it can cause physical and mental problems, and limitations to the patient's social role and ac- tivities. Therefore, CKD patients, especially those receiving hemodialysis, always need care and support from healthcare professionals, especially from their family members (Haririan et al., 2013; Maslakpak et al., 2019). Care assistance from family members is needed, especially for patients undergoing hemodialysis therapy in the long-term (Smeltzer et al., 2010).

A family caregiver is someone that helps or arranges assistance for people, especially patients that cannot carry out self-care independently due to a chronic disease, disability, or aging (Farahani et al., 2016). Long-term care for hemodialysis patients affects the caregiver's physical and psychological well-being and their quality of life. It damages their family atmosphere and work organization, reduces participation in social activities, and even causes emotional stress (Mashayekhi et al., 2015). Therefore, this condition can cause physical and mental stress and become a burden to family members (Mollaoğlu et al., 2013).

Burdens that are experienced by family caregivers include physical burdens in the form of fatigue, and psychological burdens in the form of stress, depression and anxiety. Social burdens come in the form of limited time to socialize, limited communication, and changes in social roles. There are also economic burdens such as lack of finances (Jadhav et al., 2014). Family caregivers of patients undergoing hemodialysis need

\footnotetext{
* Corresponding author: Vincencius Surani, Universitas Sumatera Utara, Faculty of Nursing, Jl. Prof. Maas No. 3 Kampus USU Medan 20155, Indonesia; e-mail: vincentsurani91@gmail.com http://doi.org/10.32725/kont.2021.017 
social support and good interpersonal relationships (Bayoumi, 2014). Furthermore, support and efforts to increase the role of the caregiver in caring for patients and reduce stress and caregiver burden can be provided through family intervention programs (Crespo et al., 2016).

The family intervention program is a medium that could be carried out to increase the knowledge and attitudes of family members about problems that arise and improve their skills in solving them - easing the burden on the family, improving welfare, and optimizing the patient's condition (Ainsworth, 2020; Reinhard et al., 2012). Furthermore, it focuses on providing information about the disorder being experienced and emphasizes guidance for treatment and medication adherence (Ainsworth, 2020). Various types of interventions could be carried out such as education, increasing communication and problem-solving skills, and stress management - which enhances the patients' and their families' knowledge of diseases and the problems faced in order to improve their quality of life (Ducharme et al., 2011).

The results of previous studies that were based on programs for giving interventions to families showed that it was possible to reduce the burden and improve the quality of life of families in caring for patients with cancer (Bahrami and Farzi, 2014), reduce their anxiety and depression when treating patients with stroke (Karakurt et al., 2018), and also reduce the burden of caring for patients with heart failure (Hu et al., 2016). Therefore, this study aims to evaluate the effect of family intervention programs carried out on families and the burden of caregivers, especially in relation to taking care of family members who have CKD and are undergoing hemodialysis.

\section{Material and methods}

This study is a systematic review and we used the method of descriptive analysis. The systematic review was based on the PRISMA guidelines, and it was used as the standard in reviewing and selecting articles. PRISMA guidelines are a form of instrument that can help authors to improve the quality of the selection and review of articles in the systematic review (Equator Network, 2020).

\section{Eligibility criteria}

The inclusion criteria for the articles were as follows: the sample of the study were family caregiver's of hemodialysis patients, study design involved randomized controlled trial (RCT) and quasi-experiments, focus on measuring the caregiver burden, published in the last 5 years (2015 to 2020), fulltext and in English language.

The exclusion criteria for the articles were as follows: the sample of the study were not family caregiver's of hemodialysis patients, focus of the study was not on measuring caregiver burden, articles in the form of qualitative research, cross-sectional, case study, systematic review and meta-analysis (Annex), studies older than 5 years, not in full-text, and articles not in English.

\section{Source of search information}

The search for articles was carried out via an international electronic database consisting of EBSCO, ProQuest, and PubMed, with an article publication period ranging from 2015 to 2020 (the last 5 years), and with the criteria that the subjects are undergoing hemodialysis and have caregivers.

\section{Search strategy}

The strategy for the literature search involved using several keywords that were adjusted to the topic and title of the research using the standard Boolean Operators "and" and "or" and their equivalent words from the Medical Subject Heading (MeSH). The keywords used included "family OR caregivers OR family members OR family caregivers" AND "caregivers burden OR family burden" AND "hemodialysis OR renal dialysis". The keywords were then entered into the search box in the electronic database and filtered according to the criteria.

A sample search strategy for EBSCO is as follows: "family OR caregiver OR family members OR family caregiver" AND "caregivers burden OR family burden" AND "hemodialysis OR renal dialysis", and then filtered according to the criteria such as full-text, published in the range 2015 to 2020, academic journals, and subjects such as hemodialysis, caregivers, and in English.

\section{Article selection}

The article selection process made use of the PRISMA diagram with four stages as depicted in Diagram 1. The first stage was identification, whereby the author combines the number of articles from all searches in the database. The second stage was screening, in which the author makes a selection based on the title and abstract of the articles. Those that met the inclusion criteria were included while those that didn't were excluded. The third stage was eligibility, in which the author makes a selection based on articles with full text. Articles that met the inclusion criteria were included while those that didn't were excluded. Furthermore, articles that had been reviewed in full text and met the inclusion criteria were assessed for their methodological quality. In the fourth stage, articles that were obtained and relevant to the topic and title of the research were reviewed systematically (Equator Network, 2020).

All search result articles starting from the identification stage of each database were exported to the software bibliography using Mendeley for easy data management and to evaluate the abstract titles. The article selection process involved two individuals that independently conducted a re-assessment or the review - starting from the identification, screening, and eligibility stages. After the completion of this process and getting the results of the studies that matched the criteria, the next step was to extract the obtained data independently from each study according to the criteria in this systematic review.

\section{Assessment of methodological quality}

The methodological quality of the articles in this systematic review was assessed using the JBI Critical Appraisal Checklist guidelines. The instrument used consists of two types - which were adjusted based on the study design that fits the criteria in this systematic review. The two types of instrument were the JBI Critical Appraisal Checklist for Randomized Controlled Trial Studies which consists of 13 questions (The Joanna Briggs Institute, 2017b), and the JBI Critical Appraisal Checklist for Quasi-Experimental Studies which consists of 9 questions (The Joanna Briggs Institute, 2017a). The JBI Critical Appraisal Checklist is the instrument used for assessing the methodological quality of a study and to assess the extent to which it has addressed possible biases in its design, intervention, and analysis (The Joanna Briggs Institute, 2017b).

\section{Data extraction}

The data extracted from each of the articles that passed the selection through the PRISMA diagram consists of the author's 
name, the year the article was published, country of the study, research objectives and sample size, research design, type of intervention, validity and reliability of the instrument, statistical tests used, key findings, quality assessment, and ethics approval. Data extraction was also included for the main outcome of the study, with each article assessing and measuring the burden of caregivers as the priority outcome of each study. The results of the data extraction can be seen in Table 1.

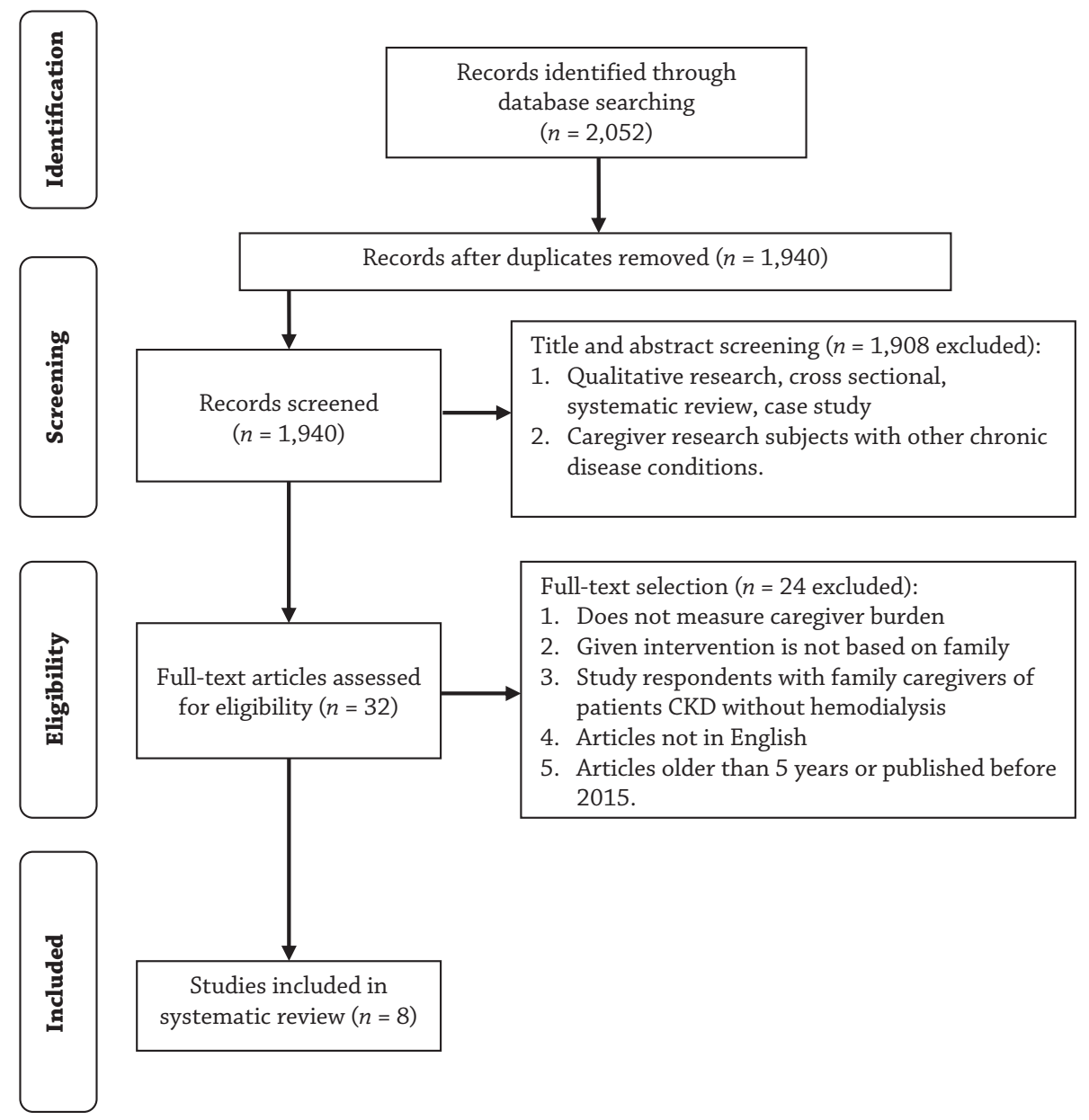

Diagram 1. Identification and selection of articles with PRISMA flow diagram

\section{Risk of bias in individual studies}

The risk assessment of bias for individual studies was carried out by looking at or determining the results from data extraction.

\section{Results}

\section{Search result}

The results of the search for articles found that the number of articles at the identification stage was 2,052 (835 from EBSCO, 646 from ProQuest, and 571 from PubMed). At the screening stage, 112 articles were excluded due to duplication. Furthermore, there were 1,940 articles at the screening stage, which were selected based on the title and abstract of the article. After selection, about 1,908 were excluded at this stage because they failed to meet the inclusion criteria. At the eligibility stage, 32 articles were selected in full text and 24 were excluded because: they did not measure the burden of caregivers, the intervention was not family-based, the respondents were patients with peritoneal dialysis, kidney transplants, or
CKD without hemodialysis, the study was not in English and/ or published before 2015. In the final stage, there were 8 articles based on the selection that had been made using the inclusion criteria.

\section{Respondent characteristics}

The total sample size from the 8 articles reviewed was 597 caregivers. The highest sample size was found in articles with the RCT design - a total of 105 respondents (Maslakpak et al., 2019). Furthermore, it was found that the respondents involved in the study were informal caregivers - and some members of their family of CKD were undergoing hemodialysis. From the 8 articles, it was found that most of the roles of family caregivers were as children, spouse (husband or wife), and parents of the patients. The average age of the respondents were in the range of 30 to 55 years, most were females, had high school education level, and the average length of family caring for patients was between 3 to 10 years. From the 8 studies in this systematic review, it was found that 6 studies were conducted in Iran, and 2 studies were conducted in Egypt. 


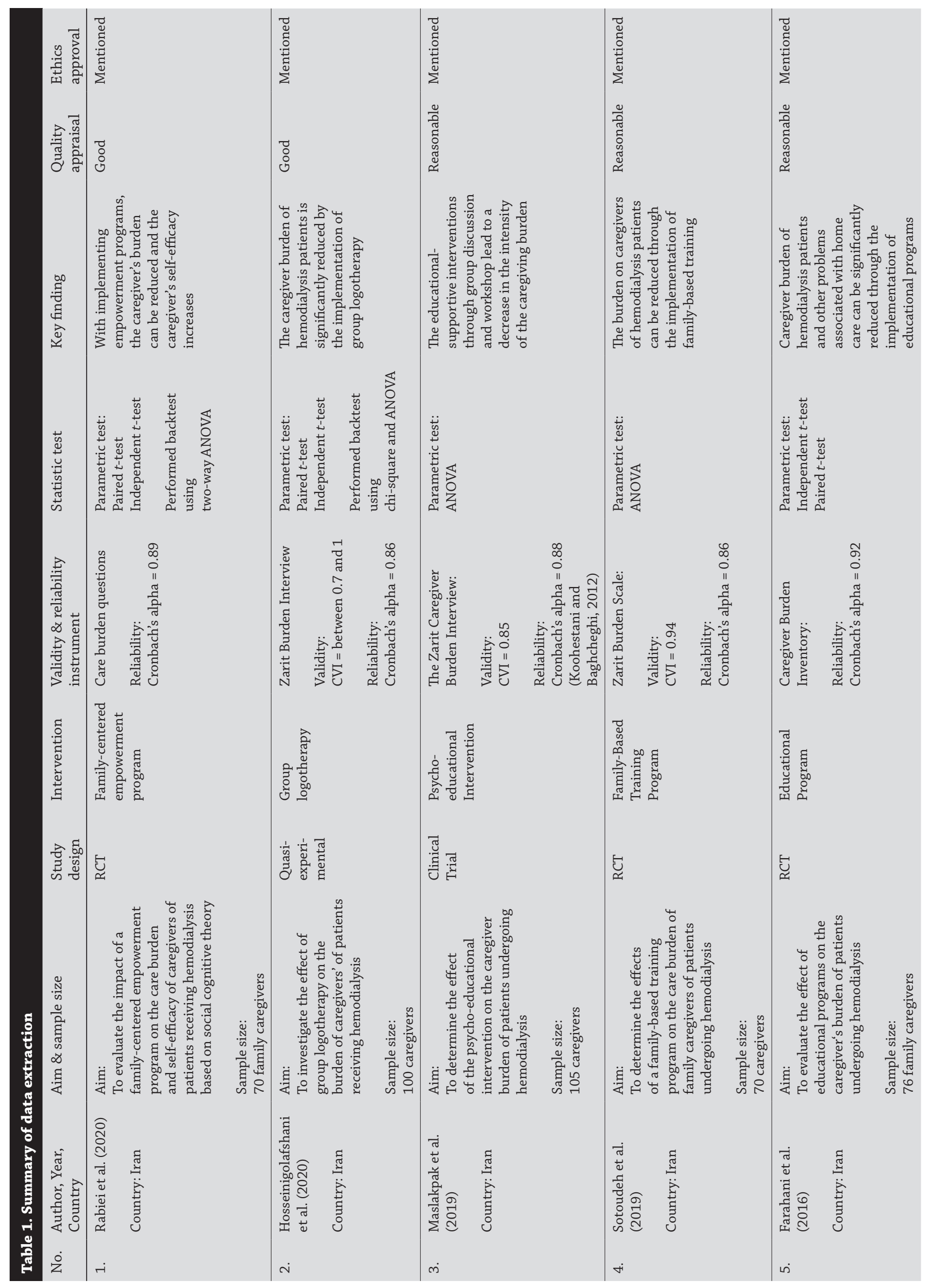




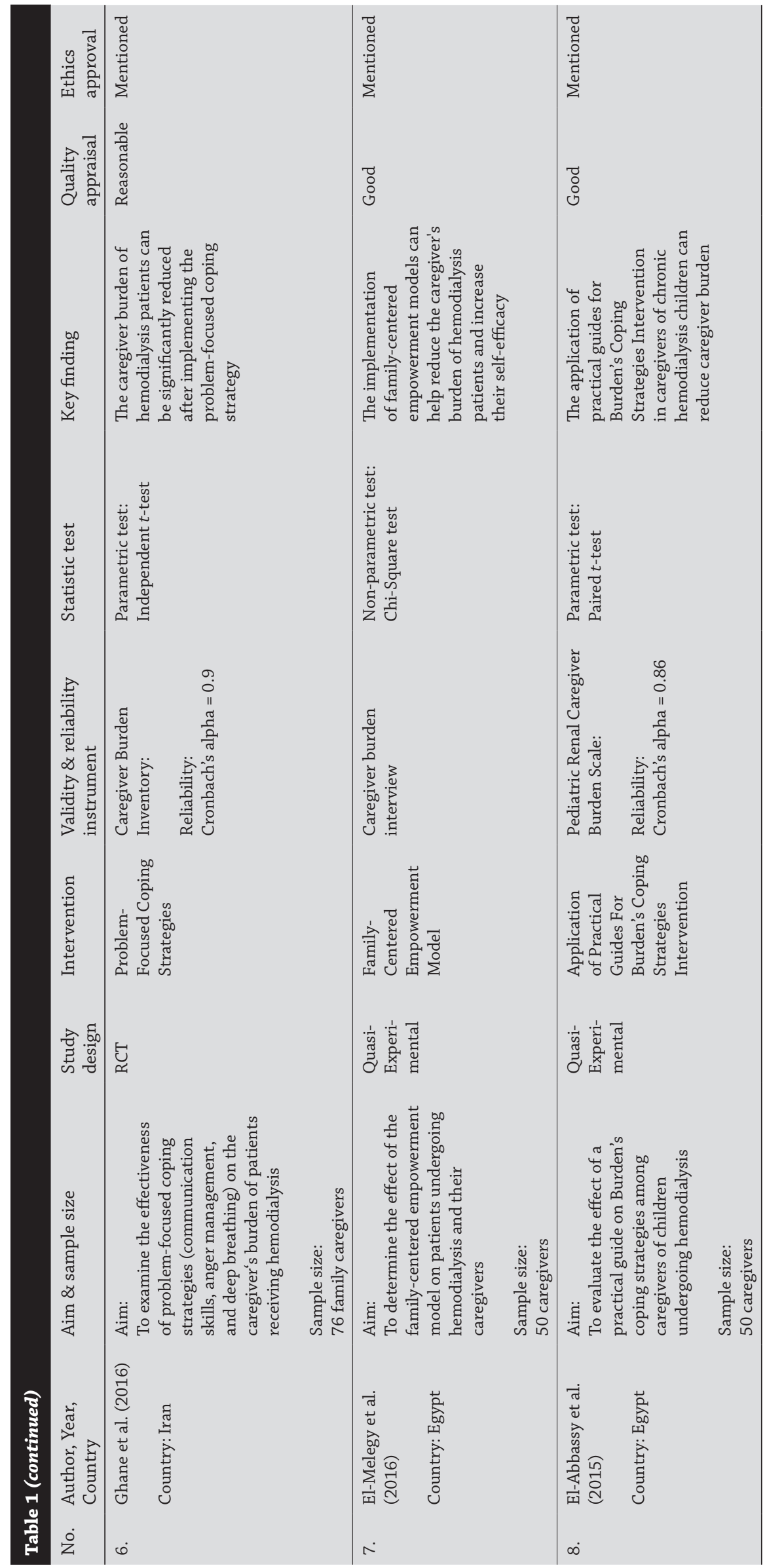




\section{Intervention characteristics}

The intervention in the 8 articles consists of several types of intervention programs given to family members of patients undergoing hemodialysis. They were categorized into 3 types of interventions, namely: family-centered, educational, and psychological. The family-centered category consists of the Family-Centered Intervention (Rabiei et al., 2020) and Family-Based Training Programs (Sotoudeh et al., 2019), and Family-Centered Empowerment (El-Melegy et al., 2016). Furthermore, the educational intervention category consists of Educational Program (Farahani et al., 2016). While the psychological intervention consists of Group Logo Therapy (Hosseinigolafshani et al., 2020), Psycho-educational Intervention (Maslakpak et al., 2019), Problem-Focused Coping (Ghane et al., 2016), and Application of Practical Guides For Burden's Coping Strategies Intervention (El-Abbassy et al., 2015).

\section{Key findings}

The results showed that the intervention program used had a significant effect on changes in (or decrease of) the burden of caregivers in treating CKD patients undergoing hemodialysis.

\section{Risk of bias in the results}

Based on the systematic review of the 8 existing articles there is still a risk of bias, because in some studies - especially those with RCT designs - there are 4 that did not include blinding techniques in their research methods (Farahani et al., 2016; Ghane et al., 2016; Maslakpak et al., 2019; Sotoudeh et al., 2019).

\section{Discussion}

This systematic review mainly focused on the types of intervention, strength of the study, and the existing limitations. Evidence from the effect of the intervention program shows that the results were significant in reducing the burden of caregivers after they were given the intervention. However, several studies in this systematic review also had some limitations.

All intervention programs in this systematic review are grouped into 3 categories. The first is the family-centered intervention, which includes family-centered intervention, family-based training, and family-centered empowerment. This type of intervention showed significant results for reducing the burden of caregivers who care for hemodialysis patients. According to a study by Ducharme et al. (2011), the family-based training program is an intervention that helps to increase the knowledge of caregivers in providing care.

According to Moattari et al. (2012), empowerment intervention is a program to further empower families independently in order for them to provide care and overcome problems that arise through various types of educational activity interventions, and to increase self-efficacy and self-esteem. This category of intervention could certainly help family caregivers to further increase their knowledge and empower families. Furthermore, it could help them to take care of hemodialysis patients and overcome problems that arise while providing care to patients.

The second category is educational intervention. According to a study by Martín-Carrasco et al. (2014), educational intervention is one of the interventions that could be carried out to solve problems, reduce caregiver stress, improve quality of life, increase welfare, and effectively reduce burdens.
Therefore, based on the results obtained in this study, educational program interventions showed a significant effect on reducing the burden of caregivers in caring for hemodialysis patients (Farahani et al., 2016). The educational materials provided in this type of intervention would certainly increase the knowledge and competence of families as caregivers in caring for hemodialysis patients. Furthermore, it could help caregivers overcome problems and prevent complications that might arise in patients while providing care.

The third category of intervention is a type of psychological intervention. This type of category includes Group Logo Therapy, Psycho-educational Intervention, Problem-Focused Coping and Practical Guides on Burden's Coping Strategies. Based on the results obtained, this category of intervention was effective in reducing the burden of caregivers when caring for hemodialysis patients. One of the existing interventions, namely psycho-educational could help caregivers in increasing comfort, and reducing stress and negative effects while providing care for hemodialysis patients (Mollaoğlu et al., 2013). Meanwhile, other types of intervention (namely increased coping) could be provided in the form of stress management, strategies to deal with anger or emotions, along with increased communication. Caregiver coping enhancement interventions help caregivers to control emotions and anger, and reduce stress when providing care for patients so that the burden will also be reduced (Ghane et al., 2016). Psychological intervention is very helpful, especially for caregivers to be able to improve the adaptation process as a result of the treatment given for a long time or even forever. It could also help them to overcome fatigue, anger, and emotions, in order to stop these aspects from causing a burden in the process of caring for the patient.

A decrease in the burden of care could help caregivers to further increase their quality of life - as well as that of hemodialysis patients. In a study conducted by Maslakpak et al. (2019), indicators that a caregiver's burden has reduced or decreased when providing care to hemodialysis patients can be seen in several aspects, such as reduced fatigue and stress, increased comfort, being able to control anger and emotions, and avoiding negative effects as a result of the long-term treatment process given to hemodialysis patients.

The interventions used from the 8 studies in this systematic review offer a basic assessment or measurementof the burden of caregivers. However, several studies make the measurements more specific or categorize the type of burden. The study by Maslakpak et al. (2019) categorizes burdens into individual, social, emotional, and economic aspects.

Furthermore, a study by Farahani et al. (2016) and Ghane et al. (2016) categorizes the burden into time dependence, developmental, physical, social, and emotional. Meanwhile, other studies only measure the burden of caregivers in general. With categorizing the type of burden, it can be seen which type of burden is the highest experienced by the caregiver. However, in this systematic review, not all studies have categorized the type of burden.

Moreover, a follow-up re-measuring the caregiver burden was carried out to further see the development of the burden of caregivers. According to the study by Nogalez-González et al. (2015), long-term observation of caregivers could reveal their level of self-efficacy. Furthermore, a high level of self-efficacy could help caregivers to control themselves, stay focused on providing care to patients and avoid the negative effects of providing long-term care to a person with chronic disease. From the 8 studies in this systematic review, the follow-up was done by re-measuring the burden of the caregivers for a maximum of 2 months (Rabiei et al., 2020). 
The caregiver's burden in caring for a patient can be influenced by several important factors. Furthermore, several studies also measure these confounding factors to see whether they correlate with the burden of caregivers. The study by El-Melegy et al. (2016) and Ghane et al. (2016) looked at the comparison or correlation between the burden and confounding factors. This included age, gender, marital status, relationship to the patient, level of education, length of caring for the patient, financial status, and duration of hemodialysis. Moreover, the study by Ghane et al. (2016) showed that there was no significant difference between confounding factors and the burdens of caregivers in the control and intervention groups. However, in the study by El-Melegy et al. (2016) there was a correlation between the level of education, the relationship to the patient, and the duration of caring for the patient to the burden of caregivers. This results correlates with confounding factors such as the demographic data of respondents.

It can also be stated that of the 8 studies used, 1 had an intervention pattern that was based on theory (Rabiei et al., 2020). The use of theory in a study could help to improve the flow of information and give the research a strong foundation and methodological design. Furthermore, the study by Rabiei et al. (2020) using social cognitive theory was based on the assumption that actualization behavior is the result of an integration between a person's cognitive, psychological, and social factors (Morton et al., 2010). The use of this theory is certainly also useful in reducing the burden on caregivers because it could be included in family-centered intervention programs. Using this theory in an intervention would also help caregivers to further increase their self-actualization in caring for hemodialysis patients through increased cognitive abilities, psychological balance, and good social relations. It would also help them make the best decisions in caring for hemodialysis patients.

\section{Limitations}

This systematic review has some limitations in relation to the 8 studies that were reviewed. The studies with the RCT design did not use blinding techniques, the follow-up time was too short to re-measure caregiver burden in just 2 months, and the majority of studies were conducted in Iran so the results of this study cannot be generalized.

\section{Further research suggestions}

The results from the studies in this review indicate that further research is still needed. Research that involves blinding tech- niques and using a control group needs to be carried out again to strengthen the results. Repeat the study in this systematic review with long follow-up periods to identify the long-term effects of the intervention on the caregiver burden. Besides, researchers also need to pay attention to other factors that contribute or have an effect and are related to the burden of caregivers.

\section{Implications for practice}

This intervention could be implemented when family members accompany the patient while undergoing scheduled hemodialysis. Family caregivers of hemodialysis patients also need attention. This is because those that provide further care require support and knowledge to further improve their ability and competence in caring for patients receiving hemodialysis in order to overcome problems that may arise. This could also increase their adaptation while providing care - and improve their quality of life.

\section{Conclusions}

The interventions from the 8 studies that were used in this systematic review can be categorized into three groups: family-centered, educational, and psychological. All of these categories showed significant results in reducing the burden on caregivers while providing care to hemodialysis patients. This systematic review could be used as evidence in carrying out family-based interventions to reduce the burden on family caregivers.

\section{Funding support}

This systematic review did not receive any financial support.

\section{Authors' contribution}

VS: creating study design, literature search, writing manuscripts. DES and MT: Guide design study, literature search, and contribution of important intellectual content during the process of drafting and revising the manuscript.

\section{Conflict of interests}

The authors have no conflict of interests to declare.

\section{Acknowledgements}

The authors would like to thank Dr. Muryanto Amin, Rector of Universitas Sumatera Utara, and Setiawan, BSN., MNS., PhD., Dean of the Faculty of Nursing, Universitas Sumatera Utara.

\section{Dopad rodinných intervenčních programů na zátěž osob pečujících o pacienty po hemodialýze}

\section{Souhrn}

Cíl: Osoby, jež pečují o rodinné příslušníky po hemodialýze, hrají ve zdravotnictví zásadní roli. Péče, kterou (zejména dlouhodobě) poskytují, však může být přičinou únavy, stresu a stát se břemenem. Cílem této přehledové studie je proto vyhodnotit účinek rodinných intervenčních programů na snižování zátěže rodinných pečovatelů.

Metody: Tento článek je systematická přehledová studie; při vyhledávání článků byly použity databáze EBSCO, ProQuest a PubMed (s použitím příslušných klíčových slov založených na tématu a názvu výzkumu). Pro výběr celkem 2052 článků byl použit vývojový diagram Preferred Reporting Items for Systematic Reviews and Meta-Analysis (PRISMA). Z celkového objemu článků bylo získáno 8 článků, které vyhověly kritériím pro zařazení a následně byly analyzovány za pomoci popisného narativního přístupu. Výsledky: Vybraných 8 článků zabývajících se rodinnými intervenčními programy, které se skládaly z intervencí zaměřených na rodinu, vzdělávacích intervencí a psychologických intervencí, vykázalo významné výsledky při snižování zátěže pečovatelů, kteří se starají o pacienty po hemodialýze.

Závěr: Výsledky této systematické přehledové studie ukazují, že intervenční programy by mohly pomoci snížit zátěž rodinných pečovatelů při péči o pacienty po hemodialýze.

Kličová slova: hemodialýza; pečovatel; rodina; zátěž 


\section{References}

1. Ainsworth M (2020). Family Intervention. [online] [cit. 202009-22]. Available from: www.neura.edu.au

2. Bahrami M, Farzi S (2014). The effect of a supportive educational program based on COPE model on caring burden and quality of life in family caregivers of women with breast cancer. Iran J Nurs Midwifery Res 19(2): 119-126.

3. Bayoumi MM (2014). Subjective burden on family carers of hemodialysis patients. Open J Nephrol 4(2): 79-85. DOI: 10.4236/ojneph.2014.42011.

4. Crespo C, Santos S, Tavares A, Salvador Á (2016). "Care that matters": Family-centered care, caregiving burden, and adaptation in parents of children with cancer. Fam Syst Health 34(1): 31-40. DOI: 10.1037/fsh0000166.

5. Ducharme F, Dubé V, Lévesque L, Saulnier D, Giroux F (2011). An online stress management training program as a supportive nursing intervention for family caregivers of an elderly person. Canadian Nurs Inform J 6(2): 1-26.

6. El-Abbassy AA, Atia M, Alam FH (2015). The effectiveness of practical guides on burden's coping strategies among caregiver of children undergoing hemodialysis. Int J NurS 2(2): 128-143. DOI: 10.15640/ijn.v2n2a13.

7. El-Melegy OA, Al-Zeftawy AM, Khaton SE (2016). Effect of family centered empowerment model on hemodialysis patients and their caregivers. J Nurs Educ Pract 6(11). DOI: 10.5430/ jnep.v6n11p119.

8. Equator Network (2020). Preferred Reporting Items for Systematic Reviews and Meta-Analyses: The PRISMA Statement. [online] [cit. 2020-09-23]. Available from: https:// www.equator-network.org/reporting-guidelines/prisma/

9. Farahani MA, Ghane G, Sydfatemi N, Hagani H (2016). Effect of educational program on the burden of family caregivers of hemodialysis patients. Evidence Based Care Journal 6(1): 7-18. DOI: 10.22038/ebcj.2016.6703.

10. Ghane G, Farahani MA, Seyedfatemi N, Haghani H (2016). Effectiveness of problem-focused coping strategies on the burden on caregivers of hemodialysis patients. Nurs Midwifery Stud 5(2): e35594. DOI: 10.17795/nmsjournal35594.

11. Haririan HR, Aghajanlo A, Ghafurifard M (2013). Evaluation of social support level among hemodialysis patients in the hospitals of Zanjan. Medical Sciences Journal of Islamic Azad University 23(1): 74-80.

12. Hosseinigolafshani SZ, Taheri S, Mafi M, Mafi MH, Kasirlou L (2020). The effect of group logo therapy on the burden of hemodialysis patients' caregivers. Journal of Renal Injury Prevention 9(4): e33. DOI: 10.34172/jrip.2020.33.

13. Hu X, Dolansky MA, Su Y, Hu X, Qu M, Zhou L (2016). Effect of a multidisciplinary supportive program for family caregivers of patients with heart failure on caregiver burden, quality of life, and depression: A randomized controlled study. Int J Nurs Stud 62: 11-21. DOI: 10.1016/j.ijnurstu.2016.07.006.

14. Jadhav BS, Dhavale HS, Dere SS, Dadarwala DD (2014). Psychiatric morbidity, quality of life and caregiver burden in patients undergoing hemodialysis. Medical Journal of Dr. D.Y. Patil University 7(6): 722-727. DOI: 10.4103/09752870.144858.

15. Jager KJ, Kovesdy C, Langham R, Rosenberg M, Jha V, Zoccali C (2019). A single number for advocacy and communication worldwide more than 850 million individuals have kidney diseases. Kidney Int 96(5): 1048-1050. DOI: 10.1016/j. kint.2019.07.012.

16. Karakurt P, Aşilar RH, Yildirim A, Bilici M (2018). The Effect of Education Given to the Caregivers of Patients with Stroke on Anxiety and Depression: An Example from Eastern Turkey. Int J Psych 3(2): 1-7. DOI: 10.33140/ijp/03/02/00001.

17. KDIGO (2017). KDIGO 2017 clinical practice guideline update for the diagnosis, evaluation, prevention, and treatment of chronic kidney disease-mineral and bone disorder (CKD-MBD). Kidney International Supplements 7(1): 1-59. DOI: 10.1053/j. ajkd.2017.07.019.

18. Koohestani H, Baghcheghi N (2012). Burn out in caregivers of patients with stroke and its related factors. Hakim Res J 14(4): 242-248.

19. Martín-Carrasco M, Domínguez-Panchón AI, GonzálezFraile E, Muñoz-Hermoso P, Ballesteros J (2014). Effectiveness of a psychoeducational intervention group program in the reduction of the burden experienced by caregivers of patients with dementia. Alzheimer Dis Assoc Disord 28(1): 79-87. DOI: 10.1097/WAD.0000000000000003.

20. Mashayekhi F, Pilevarzadeh M, Rafati F (2015). The assesment of caregiver burden in caregivers of hemodialysis patients. Mater Sociomed 27(5): 333-336. DOI: 10.5455/ msm.2015.27.333-336.

21. Maslakpak M, Torabi M, Radfar M, Alinejad V (2019). The effect of psycho-educational intervention on the caregiver burden among caregivers of hemodialysis patients. J Res Dev Nurs Midw 16(1): 13-24.

22. Moattari M, Ebrahimi M, Sharifi N, Rouzbeh J (2012). The effect of empowerment on the self-efficacy, quality of life and clinical and laboratory indicators of patients treated with hemodialysis: A randomized controlled trial. Health Qual Life Outcomes 10: 115. DOI: 10.1186/1477-7525-10-115.

23. Mollaoğlu M, Kayataş M, Yürügen B (2013). Effects on caregiver burden of education related to home care in patients undergoing hemodialysis. Hemodialysis International 17(3): 413-420. DOI: 10.1111/hdi.12018.

24. Morton RL, Tong A, Howard K, Snelling P, Webster AC (2010). The views of patients and carers in treatment decision making for chronic kidney disease: Systematic review and thematic synthesis of qualitative studies. BMJ (Online) 340(7742): 350. DOI: $10.1136 / \mathrm{bmj} . c 112$.

25. Nogalez-González C, Romero-Moreno R, Losada A, Márquez-González M, Zarit SH (2015). Moderating effect of self-efficacy on the relation between behavior problems in persons with dementia and the distress they cause in caregivers. Aging Ment Health 19(11): 1022-1030. DOI: 10.1080/13607863.2014.995593.

26. Rabiei L, Eslami AA, Abbasi M, Afzali SM, Hosseini SM, Masoudi R (2020). Evaluating the effect of family-centered intervention program on care burden and self-efficacy of hemodialysis patient caregivers based on social cognitive theory: A randomized clinical trial study. Korean J Fam Med 41(2): 84-90. DOI: 10.4082/KJFM.18.0079.

27. Reinhard SC, Levine C, Samis S (2012). Home alone: family caregivers providing complex chronic care. Washington, DC: AARP Public Policy Institute.

28. Sanyaolu A, Okorie C, Annan R, Turkey H, Akhtar N, Gray F, et al. (2018). Epidemiology and management of chronic renal failure: a global public health problem. Biostatistics Epidemiol Int J 1(1): 11-16. DOI: 10.30881/beij.00005.

29. Smeltzer S, Bare B, Hinkle J, Cheever K (2010). Brunner and suddarths textbook of medical-surgical nursing (12th ed.). Philadelphia: Wolter Kluwers.

30. Sotoudeh R, Pahlavanzadeh S, Alavi M (2019). The effect of a family-based training program on the care burden of family caregivers of patients undergoing hemodialysis. Iranian J Nurs and Midwifery Res 24: 144-150. DOI: 10.4103/ijnmr.IJNMR.

31. The Joanna Briggs Institute (2017a). Checklist for QuasiExperimental Studies (non-randomized experimental studies). [online] [cit. 2020-01-02]. Available from: https://jbi.global/ critical-appraisal-tools

32. The Joanna Briggs Institute (2017b). Checklist for Randomized Controlled Trials. [online] [cit. 2020-01-02]. Available from: http://joannabriggs.org/research/critical-appraisal-tools.html

33. USRDS (2019). Chapture 1: incidence, prevalence, patient characteristics, and treatment modalities. [online] [cit. 202001-02]. Available from: https://www.usrds.org/adr.aspx 